\title{
DNA Ligase
}

National Cancer Institute

\section{Source}

National Cancer Institute. DNA Ligase. NCI Thesaurus. Code C105960.

A family of enzymes that catalyze the formation of phosphodiester bonds to repair broken strands of DNA. 